\title{
Behavioral Intention Towards “Halal Hotels": Religiosity or Ethnicity?
}

\author{
Izwan Harith Md. Ithnan \\ New Era University College \\ 43000 Kajang, MALAYSIA \\ Ahmad Azmi M.Ariffin \\ Universiti Kebangsaan Malaysia \\ 43650 Bangi, MALAYSIA
}

\begin{abstract}
The primary purpose of this study is to empirically examine and compare the effects of religiosity and ethnicity in influencing behavioral intention towards halal hotels concept. Is it the religion or ethnic values that really matters in selecting an Islamic concept of hotel such as the halal hotel? This study involving 492 respondents randomly selected among travelers at the Kuala Lumpur International Airport used SEM as the main method to test the hypotheses. Underpinned by the Theory of Reasoned Action (TRA), the findings of this study revealed that religiosity (represented by the construct of religious commitment) significantly influence behavioral intention towards halal hotels via attitude while ethnicity (represented by ethnic identity) has no significant influence on intention to patronage a halal hotel. Theoretically, this present study help extends the TRA model by incorporating religiosity factor in the context of Islamic tourism. With regard to practical implications, the findings provide inputs to the hoteliers particularly in the hotel's positioning theme development as well as marketing communication strategies.
\end{abstract}

Key-Words: - Attitude, Halal hotels, Behavioral intention, Hospitality marketing, Religiosity, Ethnicity.

Received: October 12, 2019. Revised: February 17, 2020. Accepted: February 25, 2020.

Published: February 28, 2020.

\section{Introduction}

The tourism industry is one of the world's largest and fastest growing economic sectors which shows the number of international tourists is forecasted to reach 1.8 billion by 2030 from 1.4 billion in 2018 [1]. One of the rapidly expanding sub-sectors of the global tourism market which has started to generate significant academic interest is the "Islamic Tourism" [2,3]. According to a recent joint study by Mastercard and Crescent Rating, the Islamic tourism sector contribution to the global economy is projected to jump from USD180 billion in 2018 to USD300 billion over the next decade (Halal Travel Frontier 2019). Thus, more research are required to explore the niche market from both service providers as well as consumers perspectives to better understand its characteristics and behavior. This article is focusing on one of the most fundamental components of the Islamic tourism, which has also gathered its own momentum; the so-called halal hotel. Since the concept of halal hotel is a relatively new in most parts of the world including the Muslim nations, very little is known regarding its characteristics, forms as well as the consumption behavior of this niche hotel industry [5].

Essentially, the concept of halal refers to the producing of goods and services in the manner approved by Islamic law or shariah [6]. All Muslims must only consumed halal-certified products as Islam sets a comprehensive approach in its non-negotiable core; not just in consumption of prohibited and harmful ingredients (e.g. the prohibition of pork and alcohol) but also on the material possessions and services consumption including hotel services. As not much information is currently available regarding halal hotels and its ideal marketing strategies, it is imperative to uncover what are the underlying factors that influence purchase intention, intention to recommend as 
well as other behavioral intention towards the halal hotels [2].

Investigating behavioral intention is beneficial to tourism planning and marketing and is utmost important to understand the acceptance towards a new service offering [7] such as the halal hotels. This study was conducted in Malaysia as the country is claimed to be one of the world most popular destination for Islamic tourism [5]. In order for Malaysia to be the world hub for Islamic tourism, the concept of halal hotel needs to be strongly or wholeheartedly supported by the local people in the domestic market whereby almost 60 percent are Muslims themselves. Large majority of the Muslims in Malaysia are from the Malay ethnicity. Among the Malay Muslims society, there are certain behaviors that have been practiced primarily due to the pressure from the social forces (Malay culture), even though it is actually the requirements of the religion (Islam). This "confusion" does not only exist among the Muslim community in Malaysia but also in other parts of the Muslim world. Therefore, the findings of this study are generalizable to the Muslim market as a whole. For instance, observations showed that wearing the hijab or head cover has increasingly becoming a social expectation and a fashion trend for the Muslims women rather than as to fulfil the Islamic religious obligation [8]. In a similar vein, this study attempts to find the answer to the issue of whether intention to choose halal hotel is either primarily motivated by religiosity or ethnicity values.

The Theory of Reasoned Action, developed by Fishbein and Ajzen (1975) is employed to underpin the framework of this research. In the effort to explain behavioral intention in the context of halal hotel, this study extends the TRA model by incorporating the two explanatory variables namely "religious commitment" and "ethnic identity" to represent the religiosity and ethnicity factors respectively. The findings of this study will also address the issue of the relative influence of personal (religiosity) and social (ethnicity) factors on the intention to purchase Islamic-oriented services such as in the context of this study. Review of the related literature indicated that no studies have been carried out to examine the relative influences of religious values and ethnic values on the predictive utility of the TRA in explaining consumers' intentions to choose a halal hotel. Apart from affirming on the relationships between the two TRA variables (attitude and subjective norm) on behavioral intention in the context of halal hotel, the specific main objectives of this study are twofold:

1. To examine the effect of religious commitment on behavioral intention in the context of halal hotel.

2. To investigate the effect of ethnic identity on behavioral intention in the context of halal hotel.

\section{Literature Review}

Various research have been conducted into aspects of the interconnectedness between religion and tourism [9] and parallels are often drawn between the two [10]. In this study, Islamic tourism is defined as to any activity, event, experience or indulgence undertaken in a state of travel that is compliant with Islam, to interface within an Islamic framework with one or all of the following: history, culture, arts, heritage, way of life, economy, health, education and any other human interests [11].

\subsection{Halal Hotel}

Recently, the emergence and gradual development in the number of hotels intended to accommodate the Muslims needs such as dry hotel, shariah compliant hotel, and Islamic hotel to name a few; are exemplary scenario of the growth of Islamic tourism which present a field that is expected to be on the constant rise in the near future [2]. Researchers and hotel operators have struggled to arrive to an agreement as to what is the most appropriate term or concept that could best and comprehensively describe a hotel that operates according to the Islamic rules and regulations. Currently, the most common and widely used concept is dry hotel and shariah compliant hotel which are confusing and ultimately lead to misconceptions among academicians and practitioners. 
Dry hotel is a hotel where alcoholic beverages are not served or consumed or totally banned from the hotel premises while other facilities and operational aspects remain like other conventional ones. On the other hand, shariah compliant hotel is a hotel where the services offered and financial transactions are based on shariah principles and it is not only limited to serving halal food and beverages, but all parameters that have been designed for health, safety, environment, and the benefits on economics of all mankind, regardless of race, faith or cultures [12]. In this present study, the term halal hotel is used because the word "halal" is more understandable among the population under study. Specifically, halal hotel refers to rulings on business operations such as food, entertainment, and even gendersegregated and alcohol-free hotels and restaurants as well as 'Islamically' financed and organised activities that must be accordance to the shariah rulings [13].

\subsection{Religious Commitment}

Religiosity, being an integral part of culture, is reported to have significant influences on various dimensions of modern day's consumer behaviors [14]. However, not much is known how the influence actually occurs and subsequently affects the consumer decision making process (Nazlida \& Mizerski 2010). Religion also acts as a cultural lens through which a respondent decode the incoming message, thus directly affecting the outcome of marketing communication [16].

Religiosity has been described as the degree to which followers of one religion accept the major beliefs of that religion [17]. Hence, it is an established fact that religion plays a significant role in human behavior and attitudes [18]. Religion also affects our goals, motivation and satisfaction by influencing how we live and experience life [19].

Religious scholars and sociologists do not agree on whether adequate measures of individual religiosity can be developed and therefore such measures are subjectively devised by researchers to fit their research objectives [20]. Thus, the content and the number of religious dimensions vary considerably and may depend on the nature of the research, purpose and context [20]. In this study, the construct of religiosity is operationalized by using the Religious Commitment Inventory (RCI-10) [21]. The measurement is suitable for this study because it does not delve directly into the potentially sensitive and contentious theological religious realm, thus eliminating any possibility of offending participants or provoking their sensitivity.

\subsection{Ethnic Identity}

Ethnicity implies many dimensions, including "a sense of common customs, language, religion, values, morality, and etiquette" [22]. Even as the world's business and consumer firms try to become more global, ethnicity remains a strong inhibiting force [23].

Many argue that ethnicity is also a process of self-identification or self- labeling; whereby individuals define themselves and others into specific groups using ethnic labels [24, 25]. At the individual level, the process of selfidentification or ethnic identity is part of one's self concept which is based on his or her knowledge of membership in a social group(s) together with emotional significance and value that is attached to that membership [25].

Ethnic identity is a concept that answered the questions "What am I?" and "What am I not?" [26]. In order for such identification to occur, a sense of common ancestry, based on shared individual characteristics or shared socio-cultural experiences [27], or a sense of shared values and attitudes, or feelings of belonging and/or commitment must exist [28]. When this occurs, ethnic identity will tell a person the correctness of one's actions and at the same time allow for one to assess the correctness of an outsider's behavior [26].

As the marketplace is becoming increasingly global, understanding culturally related differences in consumer behavior is becoming critical for market researchers [29]. Although there are a growing number of studies devoted to this area, research into the role of values has been largely missing from the tourism literature, and the extant literature has failed to investigate the underlying mechanism by which values 
influence travel behavior particularly in the context of hotel selection.

\subsection{Theory of Reasoned Action (TRA)}

TRA posits that individual behavior is driven by behavioral intentions where behavioral intentions are a function of an individual's attitude toward the behavior and subjective norms surrounding the performance of the behavior [30]. Attitude is the evaluative effect of positive or negative feelings of individuals in performing particular behavior, which can be described as "the degree to which a person has a favorable or unfavorable evaluation or appraisal of the behavior in question" [31]. An individual attitude towards behavior is jointly determined by his/her salient beliefs that the behavior leads to certain outcomes and by that person's evaluation of the outcomes [32, 33]. From another angle, a person's belief is mostly influenced by subjective norms. Subjective norm is the perceived opinions of significant others who are close/important to an individual and who influence his/her decision-making, such as relatives, close friends, coworkers/colleagues, or business partners [34]. In other words, it refers to the importance of others in affecting one's thinking about how he/she should (or should not) perform the behavior in question [32, 33]. This also means that the influences of others in one's environment could create pressure on how he/she performs the behavior in question.

More specifically, the environment or servicescape of the service establishment would have a strong impact on the intention to continue patronizing the service in the future and it is also anticipated that the strength of the relationship will be contingent on the level of bonding developed between the two parties. In similar vein, the level of place attractiveness as well as the involvement of the customers would determine the quality of experience as well as intention to establish emotional attachment with the place.

TRA is open to modification or extension by altering the path and including additional predictors if it can be shown to capture a greater proportion of variance in intention after the original constructs have been taken into account
[31]. This theory is appropriate for this study as it has been shown to be applicable in various other contexts of Islamic marketing such as in the halal food purchasing [35, 36], Islamic insurance [37], Islamic pawn shops [38], Islamic home financing [39], Islamic personal financing [37], Islamic credit cards [40] and Islamic mobile phone banking [41].

\section{Conceptual Model and Hypotheses}

The figure below shows the proposed conceptual framework for this present study. By extending the Theory of Reasoned Action, the behavioral intention towards halal hotel in this study is anticipated to be significantly explained not only by the two TRA constructs namely attitude and subjective norms but also religious commitment and ethnic identity.

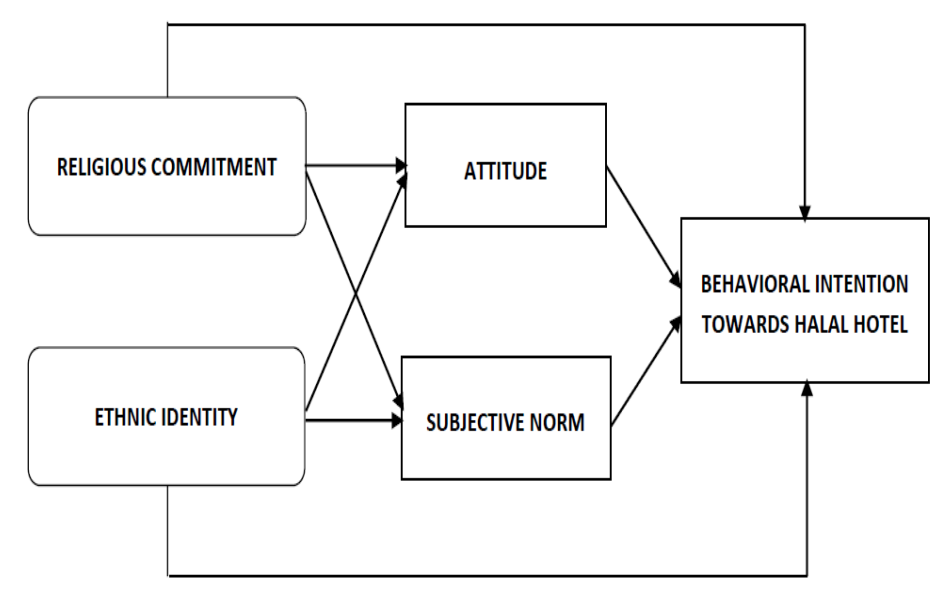

Fig.1: The Proposed Conceptual Model

\subsection{Attitude, Subjective Norm and Behavioral Intention}

The relationships between attitude, subjective norm and behavioral intention have already been widely documented by many scholars. Essentially, the TRA suggests that intention to act is determined by the favorable attitude towards the behavior as well as subjective norm or social expectation towards the behavior. The strong intention would then turn into an actual behavior [32]. In the context of Islamic marketing, both attitude and subjective norm are positively related to intention to purchase Islamic insurance [37]. Another study revealed that both attitude and 
subjective norms were significantly related to behavioral intention [36]. Interestingly, subjective norms play the most influential factor in the context of multiracial and multicultural society. Also, both attitude and subjective norm strongly influence the purchase intention of halal meat [42]. Based on these arguments, the present study proposes the following hypotheses:

H1a: There is a positive relationship between attitude and behavioral intention to choose halal hotel.

$\mathrm{H} 1 \mathrm{~b}$ : There is a positive relationship between subjective norm and behavioral intention to choose halal hotel.

\subsection{Religious Commitment, Ethnic Identity and Behavioral Intention}

Firstly, religion influences consumers' behavior in many societies $[43,44]$ and is a key determinant of consumption behavior through religious laws and individual cognition and conation [45]. One of the main facets of religion frequently examined in conjunction with consumer behavior is religious commitment which is defined as the degree to which a person uses and adheres to his or her religious values, beliefs, and practices [21]. Theoretically, religious commitment has been argued to be a greater determinant of religious behavior as it shapes motivations and behavioral intentions $[47,48,49]$.

Religious value (Islam) plays an important factor for the Muslims consumers in Malaysia to consider in forming preferences for functional foods [50]. Moreover, study related to religious commitment on consumer behavior found that casually religious respondents are trendier and more innovative than highly religious individuals [49]. Furthermore, a study also highlighted the importance of religiosity dimension on preference for shariah compliant hotels particularly in the context of Malaysia and called for further research to explore into the issue [5].

Beside religion, ethnicity can also affect a wide range of consumer behavior, such as eating habits, music, dressing preferences and choices in leisure activities [51, 52] and one of the key facets of ethnicity frequently examined in conjunction with consumer behavior is ethnic identity which is defined as one's identification with a specific ethnic group [53, 54]. It is necessary to measure the intensity of attachment to and identification with the ethnic group as it determines the level of group influence on behaviors and attitudes [55]. Moreover, a study showed that the intensity of identification with an ethnic group is a significant factor in explaining purchasing decisions [56]. In fact, most of the researchers in ethnic consumer highlight the importance of understanding the link between ethnicity and consumption $[57,55]$. Therefore, based on these arguments, the present study proposes the following hypotheses:

$\mathrm{H} 2 \mathrm{a}$ : There is a positive relationship between religious commitment and behavioral intention to choose halal hotel.

$\mathrm{H} 2 \mathrm{~b}$ : There is a positive relationship between ethnic identity and behavioral intention to choose halal hotel.

\subsection{Religious Commitment, Ethnic Identity and Determinants of TRA}

Empirical research provides evidence in support of the hypothesis that religion does influence consumer behavior in general and attitude in specific. A study found that highly religious consumers tend to be more disciplined in their daily life activities [35]. The study also indicated that the religiosity level (religious commitment) of the customers plays a significant role towards influencing their intention to undertake Islamic home financing [35].

Apart from the TRA, the theoretical explanation for the relationship between religious commitment and attitude, as well as subjective norm could be explained using the Behavioral Reasoning Theory [58]. The theory proposes that reasons serve as important linkages between beliefs and values, global motives (e.g., attitudes, subjective norms, and perceived control), intentions, and behavior. An underlying theoretical assumption in this framework states that reasons impact global motives and intentions, because they help individuals justify and defend their actions. Therefore, values (in this case is religious 
value) will affect behavioral intention through the mediation of global motives (attitudes and subjective norm), and which in the end influence the intentions and behavior.

The second factor in TRA is subjective norm which is referred to as one's own perception of the social pressures to behave or not, in a particular manner $[32,36]$. Empirical research provides evidence that religion influences consumer's social values [43]. A study found that people with a higher degree of religiosity are lesser likely to visit movie theatres, pubs, and go shopping as compared to those who attach lesser cognitive importance to religion [59]. Another study by found that highly religious individuals are more influences and getting more social pressures from their respective reference groups [60]. Finally, another related study indicated that highly religious individuals are also prone to be influenced by the religious reference groups [61].

Furthermore, a study to investigate the determinants of halal meat consumption in France, in which attitude, subjective norm and perceived behavioral control were tested empirically using Muslim self-identity and acculturation as a moderating variable [42]. The findings showed that self-identity plays a significant role in influencing their purchase decision for halal meat. As mentioned earlier, a person's ethnic identity involves one's sense of belonging to a group, as well as the feelings that go with being part of that group which is based on his or her knowledge of membership in a social group(s) together with emotional significance and value that is attached to that membership [25]. Hence, behavioral intentions towards halal hotel is expected to be influenced by how a consumer's personal value (attitude) and social values (subjective norm) dictates his or her sense of identification with a particular group [62].

Empirical research provides evidence in support the influence of ethnic identity on attitude as well as subjective norm; whereby a study argued that individuals with strong ethnic identity would manifest themselves in attitudes and socio-cultural practices of the specific ethnic group in which they belong [63].
Furthermore, a study found that those people who identify themselves with a specific ethnic group tend to incorporate norms, habits and tradition of this culture and would be encouraged to engage in a particular behavior in accordance with the shared norms of the ethnic group [64].

Hence, values (ethnic value) will affect behavioral intention through the mediation of global motives (attitudes and subjective norm), and which in the end influence intentions and behaviour [58]. On the basis of the above discussions, the following hypotheses have been proposed:

H3a: There is a positive relationship between religious commitment and attitude.

$\mathrm{H} 3 \mathrm{~b}$ : There is a positive relationship between religious commitment and subjective norm.

H4a: There is a positive relationship between ethnic identity and attitude.

$\mathrm{H} 4 \mathrm{~b}$ : There is a positive relationship between ethnic identity and subjective norm.

\section{Research Method}

Regarding the sample size, a total of 300 respondents are targeted for this study. This target was set based on the recommendation for studies that intend to employ Structural Equation Modelling (SEM) technique [65]. The data of this present study was primarily collected using questionnaire survey. Since there is no readily available sampling frame representing the population of this study (Muslim consumers in Malaysia), a nonprobability sampling method is employed. When theoretical generalizability is the main priority over population generalizability as in the case of this study, employing nonprobability sampling is an appropriate option [66]. The respondent must be a Muslim, Malay, and Malaysian as well as can be considered as a fairly frequent travelers (staying at least twice a year in hotels).

Since purposive sampling gives the researcher the authority to select a more representative sample that can bring more accurate information, the data has been collected at the Kuala Lumpur International Airport (KLIA). As the main commercial airline 
hub for Malaysia, KLIA is frequented by travelers from all over the country and therefore can be considered as a perfect field for data collection to intercept this segment who are likely to stays in hotels [67]. Respondents were approached inside the boarding gates of the departure halls while they were waiting for their flights. Another main reason why collecting tourism data at the departure halls or airports is appropriate is because respondents would have ample time to response to the survey after check-in.

In order to obtain the targeted 300 samples, a total of 450 questionnaires were administered at the KLIA airport. Out of these, 392 were returned, recording a response rate of 87.1 percent. Prior to conducting further analysis, the collected data were tested to ensure the assumptions of multivariate analysis were met. Initially, the descriptive statistics and the missing item analysis were conducted on all variables. Eighteen of the 392 returned questionnaires need to be discarded due to outliers, thus only 374 questionnaires were usable for further analysis.

With regards to the measurement developments, the ethnic identity construct was designed to measure an individual's adherence to a particular ethnic. In addition to four items adapted from the study, two new items were developed based on the literature review and personal interviews with four academicians of the Malay studies [68]. The construct of religious commitment was measured by using the Religious Commitment Inventory (RCI-10) scale [21]. The scale measures motivational and behavioral commitment to a religious value system, irrespective of the content of beliefs in that faith system and has been validated across different samples. The measurements for attitude (seven items), and subjective norm (three items) were all adapted from previous study [69]. All constructs were measured using 6-point scale from 1(strongly disagree) to 6(strongly agree). The whole instrument was pre-tested before conducting a pilot study involving 100 respondents. With Cronbach alphas of exceeding 0.7 , the results indicated that all measurements were considered valid for further analysis.

\section{Research Findings}

\subsection{Measurement Model Assessment}

In this present study, the measurement models were run simultaneously through CFA and this procedure is called 'Pooled-CFA'. Figure 2 summarizes the results of the measurement model. The results of the PooledCFA as summarized in Table 1 showed an adequate fit of the model.

Table 1. Model Fit Indexes

\begin{tabular}{|c|c|c|c|c|c|}
\hline $\mathrm{N}_{0}$ & $\begin{array}{c}\text { Name of Model } \\
\text { Fit Category }\end{array}$ & $\begin{array}{c}\text { Name of } \\
\text { Index }\end{array}$ & $\begin{array}{c}\text { Level of } \\
\text { Acceptance }\end{array}$ & $\begin{array}{l}\text { Index for } \\
\text { the study }\end{array}$ & Comments \\
\hline 1. & Absolut fit & RMSEA & $<0.08$ & 0.067 & \multirow{3}{*}{ The required level is achieved } \\
\hline 2. & Incremental fit & $\mathrm{CFI}$ & $>0.90$ & 0.902 & \\
\hline 3. & Parsimonious fit & Chisq df & $<3.0$ & 2.650 & \\
\hline
\end{tabular}

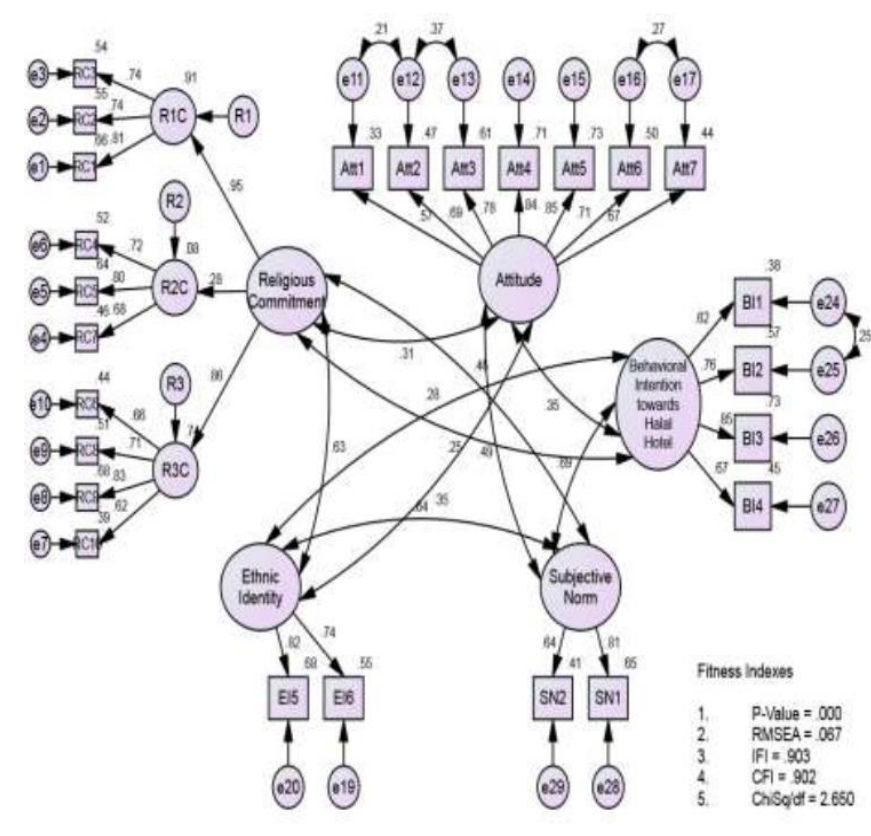

Fig.2: Pooled-CFA

The discriminant validity of this study was achieved by developing the Discriminant Validity Index Summary as well as when all redundant items are either deleted or constrained as 'free parameter' and are shown in Table 2. The diagonal values (in bold) are the square root of AVE of the construct while other 
values are the correlation between the respective constructs. In order to achieve the discriminant validity for all constructs, the diagonal values must be higher than the values in its row and column. Therefore, based on the results presented in Table 2, it can be concluded that the discriminant validity for all constructs in this present study was achieved. The convergent validity of the measurement model in this study was achieved by ensuring all values of Average Variance Extracted (AVE) exceed 0.50. Based on the findings summarized in Table 3, the convergent validity for all constructs in this present study was achieved as all values of AVE exceed 0.50 .

Table 2. The Discriminant Validity.

\begin{tabular}{|c|c|c|c|c|c|}
\hline Construct & $\mathrm{EI}$ & $\mathrm{RC}$ & $\mathrm{Att}$ & SI & $\mathrm{BI}$ \\
\hline $\mathrm{EI}$ & 0.78 & $\cdot$ & $\cdot$ & $\cdot$ & $\cdot$ \\
\hline $\mathrm{RC}$ & 0.63 & 0.76 & $\cdot$ & $\cdot$ & $\cdot$ \\
\hline $\mathrm{AIt}$ & 0.35 & 0.31 & 0.74 & $\cdot$ & $\cdot$ \\
\hline $\mathrm{SI}$ & 0.64 & 0.46 & 0.49 & 0.73 & $\cdot$ \\
\hline $\mathrm{BI}$ & 0.28 & 0.25 & 0.35 & 0.69 & 0.73 \\
\hline
\end{tabular}

Table 3. The CFA Report

\begin{tabular}{|c|c|c|c|c|}
\hline Construct & Item & Factor loading & CR (Minimum 0.6) & AVE (Minimum 0.5) \\
\hline \multirow{7}{*}{ Ethnic Identity } & EIl & deleted & \multirow[t]{7}{*}{0.757} & \multirow[t]{7}{*}{0.610} \\
\hline & EI2 & deleted & & \\
\hline & EI3 & deleted & & \\
\hline & EI4 & deleted & & \\
\hline & EI5 & 0.82 & & \\
\hline & EI6 & 0.74 & & \\
\hline & EI7 & deleted & & \\
\hline \multirow{13}{*}{$\begin{array}{l}\text { Religious } \\
\text { Commitment }\end{array}$} & R1C & 0.95 & \multirow[t]{13}{*}{0.773} & \multirow[t]{13}{*}{0.574} \\
\hline & $\mathrm{R} 2 \mathrm{C}$ & 0.28 & & \\
\hline & $\mathrm{R} 3 \mathrm{C}$ & 0.86 & & \\
\hline & $\mathrm{RCl}$ & 0.81 & & \\
\hline & $\mathrm{RC2}$ & 0.74 & & \\
\hline & RC3 & 0.74 & & \\
\hline & RC4 & 0.72 & & \\
\hline & RC5 & 0.80 & & \\
\hline & $\mathrm{RC7}$ & 0.68 & & \\
\hline & RC6 & 0.66 & & \\
\hline & RC8 & 0.71 & & \\
\hline & RC9 & 0.83 & & \\
\hline & $\mathrm{RCl0}$ & 0.62 & & \\
\hline \multirow[t]{7}{*}{ Attitude } & Attl & 0.57 & \multirow[t]{7}{*}{0.891} & \multirow[t]{7}{*}{0.542} \\
\hline & Att2 & 0.69 & & \\
\hline & Att3 & 0.78 & & \\
\hline & Att4 & 0.84 & & \\
\hline & Att5 & 0.85 & & \\
\hline & Att6 & 0.71 & & \\
\hline & Att7 & 0.67 & & \\
\hline \multirow[t]{3}{*}{ Subjective Norm } & SN1 & 0.64 & \multirow[t]{3}{*}{0.692} & \multirow[t]{3}{*}{0.533} \\
\hline & SN2 & 0.81 & & \\
\hline & SN3 & deleted & & \\
\hline \multirow[t]{4}{*}{ Behavioral Intention } & BIl & 0.62 & \multirow[t]{4}{*}{0.818} & \multirow[t]{4}{*}{0.533} \\
\hline & BI2 & 0.76 & & \\
\hline & $\mathrm{BI} 3$ & 0.85 & & \\
\hline & BI4 & 0.67 & & \\
\hline
\end{tabular}

The reliability of a research instrument concerns the extent to which the instrument yields the same result on repeated trials and how reliable the instrument in measuring the intended latent construct. For this study, the following criteria were examined and must be fulfilled simultaneously:

a) The AVE values $>0.50$ which indicate the reliability of the measurement model in measuring the construct.

b) The $\mathrm{CR}>0.60$ which indicates that the composite reliability is achieved.

Therefore, based on the findings presented in Table 3, it can be concluded that the reliability assessment of the measurement model in this present study was achieved. 


\subsection{Structural Model Assessment}

After the assessment of the measurement model, the next step is to model these constructs into the structural model for analysis using SEM as presented in Figure 3. The analysis showed that the correlation between exogenous constructs of religious commitment and ethnic identity is 0.78 (correlation is below 0.85 ). This value is crucial as it indicates that the discriminant validity between exogenous constructs is achieved and ultimately confirmed that both exogenous constructs are not redundant [70]. The result also revealed that the value of the coefficient of determination or $\mathrm{R}^{2}$ is 0.54 indicating that the contribution of religious commitment and ethnic identity in estimating the endogenous construct of behavioral intention towards halal hotel is 54 percent.

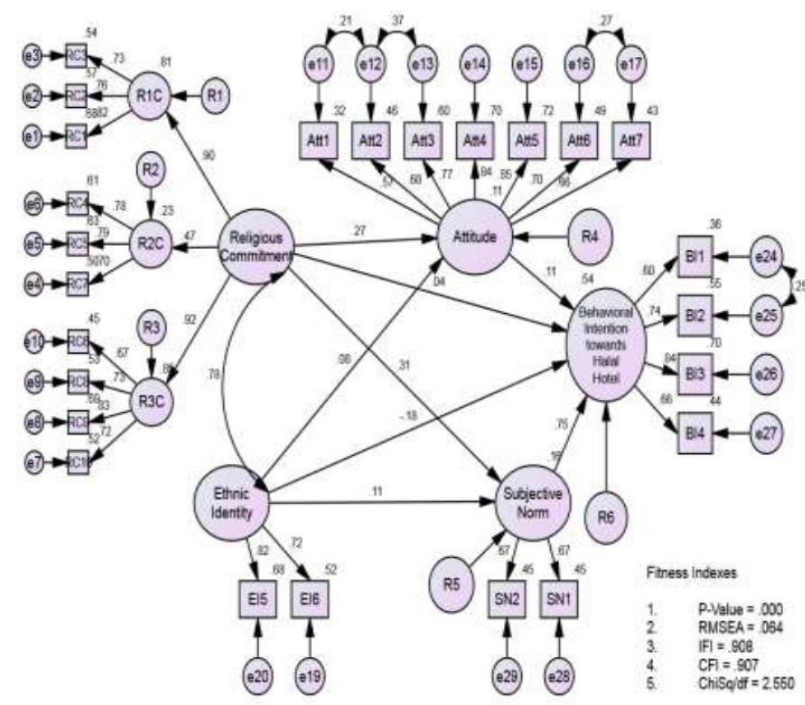

Fig.3: Structural Model
The results of path analysis as summarized in Table 4 showed four out of eight direct path coefficients were statistically insignificant. The four involved the paths between religious commitment and behavioral intention, ethnic identity and behavioral intention, ethnic identity and attitude, as well as ethnic identity and subjective norm. The path or relationship between attitude and behavioral intention was found to be statistically significant with standardized coefficient value of 0.103 , at $p<$ .05. The other three paths which were found to be significant were from subjective norm to behavioral intention $(0.721, \mathrm{p}<.05)$, religious commitment to attitude $(0.270, \mathrm{p}<.05)$, and religious commitment to subjective norm $(0.279, \mathrm{p}<.05)$.

Table 4. Path Coefficients

\begin{tabular}{|l|c|c|c|c|c|c|c|c|}
\hline & Construct & & Construct & Estimate & S.E & C.R & P & Results \\
\hline H1a & BI & $<---$ & Att & .103 & .052 & 1.985 & .047 & Suppotted \\
\hline H1b & BI & $<---$ & SN & .721 & .111 & 6.501 & .010 & Suppotted \\
\hline H2a & BI & $<---$ & RC & .005 & .105 & .045 & .964 & Not Suppoited \\
\hline H2b & BI & $<----$ & EI & .078 & .072 & 1.084 & .278 & Not Suppoited \\
\hline H3a & Att & $<---$ & RC & .220 & .111 & 1.992 & .046 & Suppoited \\
\hline H3b & SN & $<---$ & RC & .279 & .126 & 2.206 & .027 & Suppotted \\
\hline H4a & Att & $<---$ & EI & .050 & .078 & .637 & .524 & Not Suppoited \\
\hline H4b & SN & $<---$ & EI & .035 & .090 & .387 & .699 & Not Suppoited \\
\hline
\end{tabular}

\section{Discussions}

\subsection{The Relationships between the TRA Variables (Attitude and Subjective Norm) and Behavioral Intention in the Context of Halal Hotel.}

With regard to the relationships between the TRA variables (Attitude and Subjective Norm) and Behavioral Intention in the context of halal hotel, the findings show significant effects of the relationships between TRA variables and behavioral intention in the context of halal hotel, which is consistent with the TRA and previous empirical and meta-analysis studies which utilized TRA; especially in the context of Islamic marketing research $[40,36,30]$. 
In relation to TRA variables and behavioral intention in the context of halal hotel, the Malay Muslims' actual behavior towards halal hotel can be predicted through behavioral intention towards halal hotel, which is a function of two basic determinants [30, 71]. First determinant includes individuals' favorable and unfavorable evaluation about staying in a halal hotel or "attitude" towards halal hotel. Second determinant is the subjective norm which is defined as 'the individuals' beliefs about what are important referents think he/ she should do about staying in a halal hotel".

Specifically, the findings showed that although both TRA variables significantly effects Behavioral Intention of the Malay Muslims in the context of halal hotel, Subjective Norm was slightly a more powerful determinant of behavioral intention compared to Attitude. Hence, the finding is consistent with the Theory of Reasoned Action and previous empirical and meta-analysis studies [32, 33, 72]. More specifically, according to the TRA, a person's belief is mostly influenced by subjective norms; which refers to the importance of others in affecting one's thinking about how he/she should (or should not) perform the behavior in question [30].

Theoretically, the findings can also be explained based on the Social Identity Theory [73]. According to the theory, individuals aim to develop and enhance their self-image and self-esteem by a process of self-categorization, classifying themselves and others into particular groups, which in turn manifest into behavior that appropriate to that particular group identity. Therefore, in the context of halal hotel services which is publicly visible, the Malay Muslims' feel that social factor (external factor) such as the social pressure and expectation has a substantially higher effect compared to personal factor (internal factor). Thus, social factor (subjective norm) is more influential in motivating the Malay Muslims to stay in a halal hotel as a way to confirm with the social pressure and expectation.

However, as mentioned earlier, attitude is also significantly influencing behavioral intention in the context of halal hotel, indicating that although subjective norm is more influential, it might need to be triggered from one inner-self. They need to have the right attitude with a strong faith or belief in the first place. Thus, a Malay Muslim might be influenced by people who are close and important to him or her to stay in a halal hotel, but the intention to stay in a halal hotel is likely to increase if he or she have the right attitude with a strong belief that as a Muslim, he or she should choose to stay in a halal hotel. As a result, the decision to choose halal hotel by a Malay Muslim is a reflection of him or her of having the right attitude as a Muslim towards halal hotel and simultaneously fulfilling the expectation of others who are close and important to him or her. Future studies might want to investigate the causal relationship between attitude and subjective norm in the context of halal hotel.

\subsection{The Relationship between Religious Commitment and Behavioral Intention in the Context of Halal Hotel.}

The findings of this study showed no direct relationship between Religious Commitment and behavioral intention in the context of halal hotel. Instead, the relationship is indirect through both of the TRA variables (attitude and subjective norm). The Malay Muslims would not likely to choose a halal hotel or recommend the hotel to others just simply because they are considered as strongly committed Muslims. Specifically, the findings indicated that even though the religious commitment (religious value) is strong, it would not going to have an impact on the Malay Muslims intention to choose a halal hotel if they do not have favorable attitude (personal factor) and strong subjective norm (social factor) towards a halal hotel.

The results of this study indicate that religious commitment is positively related to both attitude and subjective norm and both of these variables then are significantly related to behavioral intention in the context of halal hotel. Those Malay Muslims with strong religious commitment hold a religious belief that as Muslims, they must always choose halal offerings over other conventional offerings. In the context of this study, apart from having the 
strong faith by following the Shariah Law, highly committed Muslims also belief that a halal hotel is not only the right thing to do but also actually a better choice accommodation, as well as beneficial to them. In sum, they would consider staying in a halal hotel as a good practice and have a favorable evaluation about staying in a halal hotel.

Subjective norm refers to consumers' perception towards social normative push. In the Muslim community, family and relatives, friends and colleagues, neighbors and communities are playing important roles in one consumption behavior. The Islamic values and teaching form the foundation of the Malay Muslims community where Islam encourages its followers to take collective actions. The more religious an individual, the more likely he or she will act according to the social norm or practice. As the Malay Muslims hold a strong social value, choosing a halal hotel is perceived to be a consumption decision which could not only prevent sinful action but also help enhance the social acceptance towards an individual.

The findings demonstrated the mediating role of Attitude in linking religious commitment and behavioral intention to choose halal hotel. The mediating role of Attitude is consistent with the Behavioral Reasoning Theory, which states that reasons serve as important linkages between beliefs (e.g., attitudes), global motives, intentions, and behavior [58]. This study proves that personal/internal factor (Attitude) serves as the reason that would solidify the global motives and confidently form the intentions to pursue (or not pursue) the behavioral intention to choose halal hotel among the Malay Muslims in Malaysia. Thus, the stronger the attitude (eg. desirableness and favorableness) of the Malay Muslims have towards a halal hotel, the more likely they would develop strong reasons to support the behavioral intention to choose a halal hotel.

The mediating role of subjective norm on the relationship between religious commitment and behavioral intention to choose halal hotel could also be explained using the Social Identity Theory. According to this theory, people develop a sense of self from the groups to which they belong and this membership has a significant value [64]. Therefore, the individual's sense of identification with a group encourages participation towards a brand or in a brand community [62]. In this study, behavioral intention towards an Islamic tourism "brand" which gathers much attention in the Islamic marketing domain which is known as halal hotel is proving to be influenced by social factor (subjective norm) as the Malays community may on some occasions evaluates and judges certain behavior as a social expectation rather than as to fulfill the Islamic religious obligation such as in the case of wearing the hijab or head cover [8]. Thus, the stronger the subjective norm (e.g. social pressure and expectation) of the Malay Muslims have towards a halal hotel, the more likely they would choose to stay in a halal hotel.

As mentioned earlier, the relationship between religious commitment and behavioral intention to choose halal hotel does not occur directly but indirectly through attitude and subjective norm. Subjective norm is slightly more powerful compared to Attitude as a mediator influencing the relationship between religious commitment and behavioral intention in the context of halal hotel. However, the difference is very minimal. Thus, it can be concluded that both attitude and subjective norm are equally important. Attitude and subjective norm are the variables that were fully responsible in explaining the relationship between religious commitment and behavioral intention to choose halal hotel. 


\subsection{The Relationship between Ethnic Identity and Behavioral Intention in the Context of Halal Hotel.}

The findings of this study revealed no direct relationship between ethnic identity and behavioral intention in the context of halal hotel. Furthermore, the study also found no mediating effect of attitude and subjective norm in the relationship between ethnic identity and behavioral intention to choose halal hotel. In general, it is not wrong to conclude that ethnic identity (ethnic value) or 'Malayness' in the context of this present study has nothing to do with the decision to choose a halal hotel directly as well as indirectly. In other words, the concept of ethnic identity (ethnic value) or 'Malayness' in the perspective of this study is totally separated and different from the Religious Commitment (religious value) in influencing the behavioral intention towards a halal hotel.

Specifically, the decision on halal hotels is totally a different scenario from the earlier study in the case of wearing the hijab or head cover among the Malay Muslims women in Malaysia [8]. In the context of halal hotel, the Malay Muslims in Malaysia do not choose or recommend a halal hotel because they are of Malay ethnicity but because they are Muslims. Being a Malay who strongly identify him or herself with the Malay values and identity does not influence the consumption decision whether to choose and talk positively about a halal hotel or not. Although Malay and Islam seem to be almost inseparable, the two actually have distinct values altogether when it comes to the decision-making on hotels patronage.

The insignificant result on the relationship between ethnic identity (Malayness) and Attitude as well as subjective norm showed that, being Malay does not mean the individual would have a certain belief (eg. favourable or not favourable) towards a halal hotel. Also, being a Malay does not mean the individual is expected to conform to the social expectation of the Malay community to choose a halal hotel. Perhaps, the Malays perceived the issue on halal and haram as not that relevant in the context of hotel patronage as compared to the contexts of food consumption and dressing.
Almost 98 percent of hotels in Malaysia are conventional or dry hotels and the Malays have been staying and utilizing these hotels without any notification from the related local Muslim authorities. They do not see staying at the conventional hotels without consuming the haram food and drink as unlawful from the Islamic perspective.

\section{Limitations and Suggestions for Future Research}

This study identifies several key points as the research limitations and suggestions for future research. This study relies solely on the survey instrument to capture the factors in influencing the state of consumers' behavior intention to choose a halal hotel. Survey method may be subjected to responses bias as respondents might provide their own opinion which is sometimes does not reflect the actual case [74]. In seminal text entitled "Sociological Paradigms and Organizational Analysis" the notion of paradigm were applied to the social sciences and described quantitative and qualitative methodologies are generally associated, respectively, with the two principal research paradigms which are generally labeled positivism and phenomenology [75]. Consequently, in order to achieve the comprehensive view of research data, combination of survey and unstructured interviews is suggested to be implemented for data gathering in the future study as the research would yield better insights of the relatively new concept called halal hotel.

The study focuses only on the Malays ethnic in Malaysia. In Malaysia, although the Malays are the dominant ethnic group in the country and Islam is regarded as an inseparable part of Malay ethnicity and practiced by around $60 \%$ of the population, there are other main ethnic groups (Chinese and Indian). Therefore, future studies should implement comparative study which also includes other ethnic groups as well. Furthermore, ethnic divisions are obviously visible in Malaysia which individual ethnicities having their own perception of social reality [8]. This could enrich the research findings and perhaps offer better understanding of behavioral intention to choose a halal hotel in the context of multi-racial country such as Malaysia. 


\section{Conclusion}

This present study is expected to fill the gap in understanding of Islamic tourism issue that has yet to be examined - the relative influences of religious values and ethnic values on the predictive utility of the TRA in explaining consumers' intentions to choose or visit a halal hotel. The present study has contributed in explaining the extent to which the two explanatory variables (religious commitment and ethnic identity) are related to behavioral intention as well as how they are linked to the two variables of TRA namely attitude and subjective norm.

The present study proposed the TRA to explain the mechanism linking religious commitment and ethnic identity to behavioral intention to choose a halal hotel. Consequently, it has made several findings. First, there is a direct relationship between attitude and subjective norm on behavioral intention to choose a halal hotel. Second, there is a direct relationship between religious commitment on both attitude and subjective norm. Third, attitude and subjective norm fully mediates the relationship between religious commitment and behavioral intention to choose a halal hotel. Finally, attitude and subjective norm do not mediate the relationship between ethnic identity and behavioral intention to choose a halal hotel.
From the theoretical perspective, this research has extended the existing studies by putting together religious values, ethnic values and TRA's variables in one model. In terms of managerial implication, this study has provided evidence that religious value (religious commitment) has the significant effect on behavioral intention to choose a halal hotel. Hence, managers or hotel operators should emphasize on the religious value rather than ethnic value when designing marketing plan and outlining the positioning strategy of a halal hotel. Some relevant studies can be found in [76]. The main articles used to underpin this present study are $[77,78,79,80,81$ and 82$]$.

\section{Acknowledgement:}

This study is partly funded by the Malaysian Ministry of Higher Education: FRGS Research Grant: FRGS/1/2013/SS05/UKM/02/7. 


\section{References:}

[1] The World Tourism Organization, Statistics, 2019 available at: https://statistics.unwto.org/content/yearbooktourism-statistics. [accessed 3 October 2019].

[2] Ithnan, I. H. M., The Influences of Religiosity and Ethnicity on Behavioral Intention Towards Halal Hotel in Malaysia: The Mediating Effects of Attitude and Subjective Norm. Unpublished doctoral dissertation, Bangi: Universiti Kebangsaan Malaysia, 2016.

[3] Hall, C. M., \& Prayag, G., Emerging and Future Issues in Halal Hospitality and Islamic Tourism. The Routledge Handbook of Halal Hospitality and Islamic Tourism, 2019.

[4] Halal Travel Frontier, Report, 2019 available at:

https://www.crescentrating.com/reports/halaltravel-frontier-2019.html. [accessed 3 October 2019].

[5] Othman, N. H., Ariffin, A. A. M. and Ithnan, I. H. M., The influences of religiosity dimensions on preference for shariah-compliant hotels. Advanced Science Letters, 21(6), 2015, pp. 2095-2099.

[6] Albattat, A., Ahmad Pitra, J., Mahendran, N. A. P. \& Azmi, A., The Impact Of Service Quality On Muslim Customers In Shariah Compliant Hotel. Journal of Tourism, Hospitality and Environment Management 3(8), 2018, pp. 1-14.

[7] Lam, T. and Hsu, C. H. C., Predicting Behavioral Intention of Choosing a Travel Destination. Tourism Management 27 (2), 2006, pp. 589-599.

[8] Mouser, A. E., Defining modern "Malay' womanhood and the coexistent messages of the veil. Religion 37, 2007, pp. 164-174.

[9] Vukonic, B., Tourism and religion. New York: Pergamon, 1996.

[10] Allcock, J. B., Tourism as a sacred journey. Society and Leisure 11, 1988, pp. 33-38.

[11] Islamic Tourism Center, Brochure, 2019. available

at: http://sotaicms.virtualmalaysia.com/domain/itc/ media/content/document/EnglishBrochure.pdf [accessed 3 October 2019].

[12] Muhammad, Z., Al Jawhara: Promoting Islamic hospitality and Halal tourism. The Halal Journal (May/June) 60, 2009.

[13] Kamali, M. H., Citizenship and accountability of government: an islamic perspective. Islamic Texts Society, 2011.

[14] Cornwell, B., Cui, C., Mitchell, V., Schelegelmilch, B., Dzulkiflee, A. \& Chan, J., A cross-cultural study of the role of religion in consumer's ethnical position. International Marketing Review 22(5), 2005, pp. 531-46.

[15] Muhamad, N. \& Mizerski, D., The constructs mediating religions' influence on buyers and consumers. Journal of Islamic Marketing 1(2), 2010, pp. 124-135.

[16] Fam, K. S., Waller, D. S. and Erdogan, B. Z., The influence of religion on attitudes towards advertising of controversial products. European Journal of Marketing 38(5/6), 2004, pp. 53755.

[17] Abdul Razak, K., Religiosity and shopping orientation: a comparative study of Malaysia and Thailand consumers. Journal of Global Business Management, 3(2), 2007.

[18] Cyril De Run, E., Mohsin Butt. M., Fam, K. S. and Yin Jong, H., Attitudes towards offensive advertising: Malaysian Muslims' views. Journal of Islamic Marketing, 1(1), 2010, pp. 25-36.

[19] Ellison, C. W. \& Cole, K. C., Religious commitment, television viewing, values and quality of life. Journal of Psychology and Christianity, 1(1), 1982, pp. 21-32.

[20] Hamza, K., Measuring Religiosity in Consumer Research From an Islamic Perspective. Journal of Economic \& Administrative Sciences, Vol. 26, No. 1, 2010, pp. 52-78.

[21] Worthington, E. L., Wade, N. G., Hight, T. L., McCullough, M. E., Berry, J. T. \& Ripley, J. S., The Religious Commitment Inventory-10: Development, Refinement and Validation of a Brief Scale for Research and Counseling. Journal of Counseling Psychology, 50, 2003, pp. 84-96.

[22] Webster, C., Effects of Hispanic Ethnic Identification on Marital Roles in the Purchase Decision Process. Journal of Consumer Research, 21, 1994, pp. 319-331.

[23] Douglas, S. P. \& Wind, Y., The Myth of Globalization. Columbia Journal of World Business 22, 1987, pp. 19-29.

[24] Rossiter, J. R. \& Chan, A. M., Ethnicity in business and consumer behavior. Journal of Business Research, 42, 1998, pp. 127-34.

[25] Tajfel, H., Human Groups and Social Categories: Studies in Social Psychology, Cambridge University Press, Cambridge, 1981.

[26] Frideres, J. A. M. E. S. \& Goldenberg, S., Ethnic identity: Myth and reality in Western Canada. International Journal of Intercultural Relations, 6(2), 1982, pp. 137-151.

[27] Kitano, H. H., Alcohol and drug use and selfesteem: A sociocultural perspective. The social importance of self-esteem, 1989, pp. 294-326. 
[28] Ting-Toomey, S., Ethnic identity and close friendship in Chinese-American college students. International Journal of Intercultural Relations, 5(4), 1981, pp. 383-406.

[29] Jamal, A., Marketing in a multicultural world: The interplay of marketing, ethnicity and consumption. European journal of marketing, 37(11/12), 2003, pp. 1599-1620.

[30] Fishbein, M. \& Ajzen, I., Belief, attitude, intention, and behavior: An introduction to theory and research. Boston: Addison- Wesley, 1975.

[31] Ajzen, I., The Theory of Planned Behavior, Organizational Behavior and Human Decision Process, 50, 1991, pp. 179-211.

[32] Ajzen, I. \& Driver, B. E., Applied of The Theory of Planned Behavior to Leisure Choice. Journal of Leisure Research, 24(3), 1992, pp. 207-224.

[33] Ramayah, T., Mohd-Nasurdin. A., Noor. M. N. \& Sin, Q. B., The relationships between belief, attitude, subjective norm and behaviour towards infant food formula selection: The views of the Malaysian mothers. Gadjah Mada International Journal of Business 6(3), 2004, pp. 405-418.

[34] Hee, S. P., Relationships among attitudes and subjective norm: testing the theory of reasoned action across cultures. Communication Studies, 51(2), 2000, pp. 162-175.

[35] Shah Alam, S., \& Mohamed Sayuti, N., Applying the Theory of Planned Behavior (TPB) in halal food purchasing. International journal of Commerce and Management, 21(1), 2011, pp. 8-20.

[36] Lada, S., Harvey Tanakinjal, G. \& Amin, H., Predicting intention to choose halal products using theory of reasoned action. International Journal of Islamic and Middle Eastern Finance and Management, 2(1), 2009, pp. 66-76.

[37] Amin, H., Rahim Abdul Rahman, A., Laison Sondoh Jr, S. \& Magdalene Chooi Hwa, A., Determinants of customers' intention to use Islamic personal financing: The case of Malaysian Islamic banks. Journal of Islamic Accounting and Business Research, 2(1), 2011, pp. 22-42.

[38] Amin, H. \& Chong, R., Is the theory of reasoned action valid for Ar-Rahnu? An empirical investigation. Australian Journal of Basic and Applied Sciences, 5(10), 2011, pp. 716-726.

[39] Amin, H., Abdul-Rahman, A. R. \& AbdulRazak, D., An integrative approach for understanding Islamic home financing adoption in Malaysia. International Journal of Bank Marketing, 31(7), 2013, pp. 544-573.

[40] Amin, H., Patronage factors of Malaysia local customers toward Islamic credit cards. Management Research Review, 35(6), 2012, pp. 512-530.

[41] Sun, S., Goh, T., Fam, K. S. \& Xue, Y., The Influence of religion on Islamic mobile phone banking services adoption. Journal of Islamic Marketing, 3(1), 2011, pp. 81-98.

[42] Bonne, K., Vermeir, I., Bergeaud-Blackler, F. \& Verbeke, W., Determinants of halal meat consumption in France. British Food Journal, 109(5), 2007, pp. 367-386.

[43] Delener, N., Religious Contrasts in Consumer Decision Behavior Patterns: their dimensions and marketing implications. European Journal of Marketing 28 (5), 1994, pp. 27- 33.

[44] Pettinger, C., Holdsworth, M. \& Gerber, M., Psycho-social influences on food choice in Southern France and Central England. Appetite. 42(3), 2004, pp. 307-16.

[45] Harrell, S., Men, women, and ghosts in Taiwanese folk religion. Gender and religion: On the complexity of symbols, 1986, pp. 97116.

[46] Wilkes, R. E., Burnett, J. J. \& Howell, R. D., On the meaning and measurement of religiosity in consumer research. Journal of the Academy of Marketing Science, 14(1), 1986, pp. 47-56.

[47] McDaniel, S. W. \& Burnett, J. J., Consumer religiosity and retail store evaluative criteria. Journal of the Academy of marketing Science, 18(2), 1990, pp. 101-112.

[48] Essoo, N. \& Dibb, S., Religious influences on shopping behaviour: an exploratory study. European Journal of Social Psychology, 29, 2004, pp. 371-389.

[49] Siti Hasnah Hassan, Consumption of functional food model for Malay Muslims in Malaysia. Journal of Islamic Marketing, 2(2), 2011, pp. 104-124.

[50] Bocock, R., 1993: Consumption. London: Routledge, 1993.

[51] Burton, E., The compact city: just or just compact? A preliminary analysis. Urban studies, 37(11), 2000, pp. 1969-2006.

[52] Dashefsky, A. \& Shapiro, H., Ethnic Identification among American Jews:Socialization and Social Structure. Lexington, Ma: Lexington Books, 1974.

[53] Driedger, L., The Canadian Ethnic Mosaic. Toronto: McClelland and Steward, 1978.

[54] Sekhon, Y. K. \& Szmugin, I., Conceptualizing ethnicity and acculturation of second 
generation Asian Indians in Britain. Academy of Marketing Science Review; (3), 2005 (online:

http://www.amsreview.org/articles/sekhon032005.pdf).

[55] Donthu, N. \& Cherian, J., Impact of Strength of Ethnic Identification on Hispanic Shopping Behavior. Journal of Retailing; 70 (4), 1994, pp. 383-393.

[56] Berry, W. J., Psychology of Acculturation. Nebraska Symposium on Motivation. Ed Dienstbier R.A. and Barman J.J.,; 37, 1989.

[57] Westaby, J. D., Behavioural Reasoning Theory: Identifying new linkages underlying linkages and behaviour. Organizational Behavior and Human Decision Processes, 98, 2005, pp. 97120.

[58] Kahle, L. R., Kau, A., Tambyah, S., Tan, S. \& Jung, K., "Religion, religiosity, and values: implications for consumer behaviour", in Haugtvedt, C.P., Merunka, D. and Warlop, L. (Eds), Proceedings of the La Londe Seminar, 32nd International Research Seminar in Marketing, La Londe-les-Maures, Sage, New York, NY, 2005, pp. 249-259.

[59] Delener, N., The effects of religious factors on perceived risk in durable goods. Journal of Consumer Marketing, 7(3), 1990, pp. 27-38.

[60] Weaver, G. R. \& Agle, B. R., Religiosity and ethical behavior in organizations: A symbolic interactionist perspective. Academy of management review, 27(1), 2002, pp. 77-97.

[61] Algesheimer, R., Dholakia, U. M. \& Herrmann, A., The social influence of brand community: Evidence from European car clubs. Journal of Marketing, 69(3), 2005, pp. 19-34.

[62] Laroche, M., Kim, C. \& Tomiuk, M. A., Italian ethnic identity and its relative impact on the consumption of convenience and traditional foods. British Food Journal, 101, 1998, pp. 201-228.

[63] Terry, D. J. \& Hogg, M. A., Group norm and the attitude-behavior relation: a role for group identification. Personality and Social Psychology Bulletin, 22, 1996, pp. 776-793.

[64] Hair, J. F. Jr., Anderson, R. E., Tatham, R. L. \& Black, W. C., Multivariate Data Analysis, 6th ed., Prentice-Hall, Englewood Cliffs, NJ., 2007.

[65] Calder, B. J., Philip, L. W. \& Tybout, A. M., Designing research for application. Journal of Consumer Research, 8(2), 1981, pp.197-207.

[66] Ariffin, A. A. M., Nameghi, E. N. \& Zakaria, N. I., The effect of hospitableness and servicescape on guest satisfaction in the hotel industry. Canadian Journal of Administrative Sciences/Revue Canadienne des Sciences de l'Administration, 30(2), 2013, pp. 127-137.

[67] Butt, M. M. \& de Run, E. C., Can Ethnically Targeted Advertising Work for Malay Adolescents?: The Moderating Role Of The Strength Of Ethnic Identity. Asian Academy of Management Journal, 17(1), 2012.

[68] Sparks, B. \& Pan, G. W., Chinese outbound tourists: understanding their attitudes, constraints and use of information sources. Tourism Management, 30(4), 2009, pp. 483494.

[69] Zainudin, A., A Handbook on Structural Equation Model (SEM) using Amos. Bangi: MPWS Publication Sdn. Bhd, 2015.

[70] Ajzen, I., Nature and operation of attitudes. Annual review of psychology, 52(1), 2001, pp. 27-58.

[71] Palmer, A., Koenig-Lewis, N. \& Jones, L. E. M., The effects of residents' social identity and involvement on their advocacy of incoming tourism. Tourism Management, 38, 2013, pp. 142-151.

[72] Turner, J. C. \& Tajfel, H., The social identity theory of intergroup behavior. Psychology of Intergroup Relations, 5, 1986, pp. 7-24.

[73] Zikmund, W. G. \& Babin, B. J., Explore Marketing Research, 9th ed., Thomson South Western, London, 2007.

[74] Burrell, G. \& Morgan, G., Sociological paradigms and organizational analysis. London: I-Ieinemann, 1979.

[75] Paul, B. \& Pascal, L., Simulation of a latent heat thermal energy storage for the solar airconditioning system of a net-zero energy hotel. WSEAS Transactions on Environment and Development. 15, 2019. pp.510-526.

[76] Akyol, $M$ and Kilinc, O., Internet and halal tourism marketing, International Periodical for The Languages, Literature and History of Turkish or Turkic, 9/8(Summer), 2014, pp.171186. Ankara-Turkey.

[77] Lam, J M and Ariffin, A A M., Do travel images affect international students' on-site academic value? New evidence from the Malaysia's' higher edutourism' destination. Journal of Vacation Marketing, 25(4), 2019, pp. 499-514.

[78] Mansour, J S and Ariffin, A A M., The effects of local hospitality, commercial hospitality and experience quality on behavioral intention in cultural heritage tourism. Journal of Quality Assurance in Hospitality \& Tourism, 2017, 18(2): pp.149-172. 
[79] Ariffin, A A M and Mansour, J S., The influences of authenticity and experience quality on behavioural intention in cultural heritage destination. WSEAS Transactions on Business and Economics, 15, 2108, pp.394403.

[80] Habibi, A and Ariffin, A A M, Value as a medical tourism driver interacted by experience quality. Anatolia, 30(1), 2019, pp.35-46.

[81] Rosli, N and Ariffin A A M, The relationships between social conservatism and preference for shariah-compliant hotels. International Journal of Management and Applied Science, 3(9), 2017, pp.36-42. 